\title{
H1-8 Gene
}

National Cancer Institute

\section{Source}

National Cancer Institute. H1-8 Gene. NCI Thesaurus. Code C162809.

This gene plays a role in chromosome instability in embryonic cells and oocytes. 